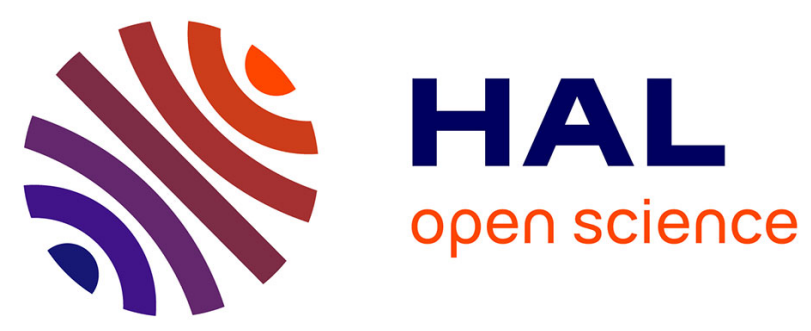

\title{
Global warming as a driving factor for cyanobacterial blooms in Lake Karaoun, Lebanon
}

Kamal Slim, Ali Fadel,, Ali Atoui, Bruno J. Lemaire, Brigitte Vinçon-Leite, Bruno Tassin

\section{- To cite this version:}

Kamal Slim,, Ali Fadel,, Ali Atoui,, Bruno J. Lemaire, Brigitte Vinçon-Leite, et al.. Global warming as a driving factor for cyanobacterial blooms in Lake Karaoun, Lebanon. Desalination and Water Treatment, 2014, 52 (10-12), pp.2094-2101. 10.1080/19443994.2013.822328 . hal-00845813

\section{HAL Id: hal-00845813 \\ https: / hal-enpc.archives-ouvertes.fr/hal-00845813}

Submitted on 22 Jul 2013

HAL is a multi-disciplinary open access archive for the deposit and dissemination of scientific research documents, whether they are published or not. The documents may come from teaching and research institutions in France or abroad, or from public or private research centers.
L'archive ouverte pluridisciplinaire HAL, est destinée au dépôt et à la diffusion de documents scientifiques de niveau recherche, publiés ou non, émanant des établissements d'enseignement et de recherche français ou étrangers, des laboratoires publics ou privés. 


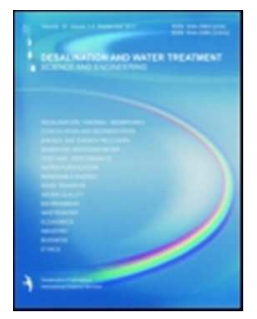

\section{Global warming as a driving factor for cyanobacterial blooms in Lake Karaoun, Lebanon}

\begin{tabular}{|r|l|}
\hline Journal: & Desalination and Water Treatment \\
\hline Manuscript ID: & TDWT-2013-0183.R1 \\
\hline Manuscript Type: & Original Paper \\
\hline Date Submitted by the Author: & $17-J u n-2013$ \\
\hline Complete List of Authors: & $\begin{array}{l}\text { slim, kamal; lebanese university, biology; lebanese atomic energy, } \\
\text { microorganisms } \\
\text { Atoui, Ali; Lebanese Atomic Energy Commission, Laboratory of } \\
\text { Microorganisms and Food Irradiation } \\
\text { Fadel, Ali; Université Paris-Est, Ecole des Ponts ParisTech, } \\
\text { Lemaire, Bruno; AgroParisTech, } \\
\text { Vinçon-Leite, Brigitte; Université Paris-Est, } \\
\text { Tassin, Bruno; Université Paris-Est, }\end{array}$ \\
\hline Keywords: & $\begin{array}{l}\text { Cyanobacterial bloom, Climate change, Microcystis aeruginosa, } \\
\text { Aphanizomenon ovalisporum, Thermal stratification, Lake Karaoun }\end{array}$ \\
\hline \multicolumn{2}{|c}{} \\
\hline
\end{tabular}

SCHOLARONE ${ }^{m}$

Manuscripts 


\title{
Global warming as a driving factor for cyanobacterial blooms in Lake Karaoun, Lebanon
}

\author{
Kamal Slim ${ }^{1}$, Ali Fadel ${ }^{1,2}$, Ali Atoui ${ }^{1}$, Bruno J. Lemaire ${ }^{2,3}$, Brigitte Vinçon-Leite ${ }^{2}$, Bruno \\ $\operatorname{Tassin}^{2}$ \\ ${ }^{1}$ Laboratory of Microorganisms and Food Irradiation, Lebanese Atomic Energy Commission- \\ CNRS, P.O. Box 11-8281, Riad El Solh, 11072260 Beirut, Lebanon \\ ${ }^{2}$ LEESU (UMR MA-102) Université Paris-Est, Ecole des Ponts ParisTech, AgroParisTech, F- \\ 77455 Marne-la-Vallée, France \\ ${ }^{3}$ AgroParisTech, 75005, Paris, France \\ (E-mail: kslim @cnrs.edu.lb); Tel : + 961 (0)1 450811 ; Fax : + 961 (0)1 450810 \\ (E-mail: ali.fadel@leesu.enpc.fr); Tel : + 33 (0)1 64153762 ; Fax : + 33 (0)1 64153764 \\ (E-mail: a.atoui@cnrs.edu.lb); Tel : + 961 (0)1 450811 ; Fax : + 961 (0)1 450810 \\ (E-mail: bruno.lemaire@leesu.enpc.fr); Tel : + 961 (0)1 64153642 ; Fax : + 33 (0)1 6415 \\ 3764 \\ (E-mail: bvl@leesu.enpc.fr); Tel : + 33 (0)1 64153639 ; Fax : + 33 (0)1 64153764 \\ (E-mail: tassin@leesu.enpc.fr); Tel : + 33 (0)1 64153640 ; Fax : + 33 (0)1 64153764
}

Corresponding author: (E-mail: kslim @cnrs.edu.lb)

\begin{abstract}
The Middle East region suffers already from the gradual effects of climate change and will be among the most vulnerable regions in the future. As a result, productivity should undergo losses due to high temperatures, drought, floods and soil degradation which threaten food security of Levantine countries. Since water is the critical factor in the region, even slight changes in air temperature and rainfall patterns will have considerable impact. It has been proven that potential climate change may disrupt, on one hand, most ecosystems through changes in their physicochemical conditions, and on the other hand the species which are living in these ecosystems. Then, the biodiversity can be found challenging. In this study, the effects of climate change on population and phytoplankton communities of Lake Karaoun were investigated since 1992. The climate regime shifts have been shown to alter the lake ecosystem. In the past, Lake Karaoun was characterized by a highly diversified microflora dominated by diatoms and green algae. Recent climatic fluctuations, with culmination in 2008-2011 and temperatures exceeding $40^{\circ} \mathrm{C}$ have upset this biodiversity. Blooms of cyanobacteria, specifically Microcystis aeruginosa and Aphanizomenon ovalisporum, have occurred and disturbed both the ecosystem and the functioning of the lake.
\end{abstract}

Keywords: Aphanizomenon ovalisporum, Climate change, Cyanobacteria, Lake Karaoun, Microcystis aeruginosa, Thermal stratification 
Presented at the 6th International Conference on Water Resources in Mediterranean Basin (WATMED6), 10-12 October 2012, Sousse, Tunisia

\section{Introduction}

Lakes and reservoirs are important resources used to complete human needs in drinking water, agricultural irrigation, power generation, industrial water supply, commercial fishing and recreational activities. Many lakes and reservoirs throughout the world are contaminated by toxic cyanobacterial species such as Microcystis aeruginosa [1], Planktothrix rubescens [2], Aphanizomenon ovalisporum [3], Cylindrospermopsis raciborskii [4]. These toxic cyanobacteria secrete cyanotoxins that are lethal to livestock, pets, wildlife and humans that ingest water contaminated with these toxic cyanobacterial cells, or toxins released from decaying cyanobacterial cells [5-7]. In addition, the growth and proliferation of this toxic cyanobacteria produces bad smell and scum, preventing recreational use of water bodies, clogging irrigation pipes and causing side effects on hydropower generation equipments [8].

Cyanobacteria dominance and bloom formation within lakes and reservoir has been forecasted as a result of global warming [9]. Global warming favours harmful cyanobacteria blooms in several ways: 1) it rises water temperature providing optimal growth rates to cyanobacteria that tends to grow at relatively high temperatures $[10,11] 2)$ strengthen vertical stratification and facilitate the formation of surface blooms by buoyant cyanobacteria that seeks nutrients and light at surface 3) lengthens the period of thermal stratification in lakes due to earlier stratification in spring and postponed destratification in late autumn [12].

In order to properly detect the water quality of Lake Karaoun after the dramatic changes over the past 5 years, we have conducted a limnological data collection at a rate of two weeks or month to assess the short-term variability of its properties physico-chemical and biological as well as the relationships between these properties and weather conditions. In a previous work, we presented the abiotic and biotic characteristics and especially fluctuations of phytoplankton communities in the years 2009-2010 [13]. Since its construction in 1965, the Lake Karaoun was characterized by oligotrophic status which manifested itself by a rich and varied biodiversity. Moreover, before 20 years, phytoplankton community in Lake Karaoun was dominated by diatom bloom that represented about $80 \%$ of the total community [14]. However, Atoui et al. [15] reported the occurrence of Aphanizomenon ovalisporum and Microcystis aeruginosa blooms in 2009 for the first time in Lake Karaoun. In this study, we tried to identify the factors that caused the appearance of this bloom. Did the change in climate change cause the phytoplankton community in Lake Karaoun?

\section{Study site}

Lake Karaoun, located in the southern part of the Bekaa plain, is the largest artificial freshwater body in Lebanon (Figure 1). The lake was constructed between 1958 and 1965 along Litani River (170 km length). It has a maximum capacity of $230.10^{6} \mathrm{~m}^{3}$. The lake is located in a semiarid climate, characterised by a moderately cold winter season and distinctly 
dry and hot summer. The annual precipitation rate in the lake area is about $800 \mathrm{~mm}$. The heaviest rainfall period is between November and April. However, the lake area is characterized with little or no precipitation between June and August [16].

The lake now serves various purposes such as: hydropower generation, fisheries and aquaculture, recreation, tourism, and irrigation through canal 900. In the last decade, the lake changed from an oligotrophic to hypertrophic state. Solid waste dumping, animal-raising farm, industrial wastes, food processing plants and other polluting activities on upper Litani river basin that supply Lake Karaoun has increased its trophic level [17].

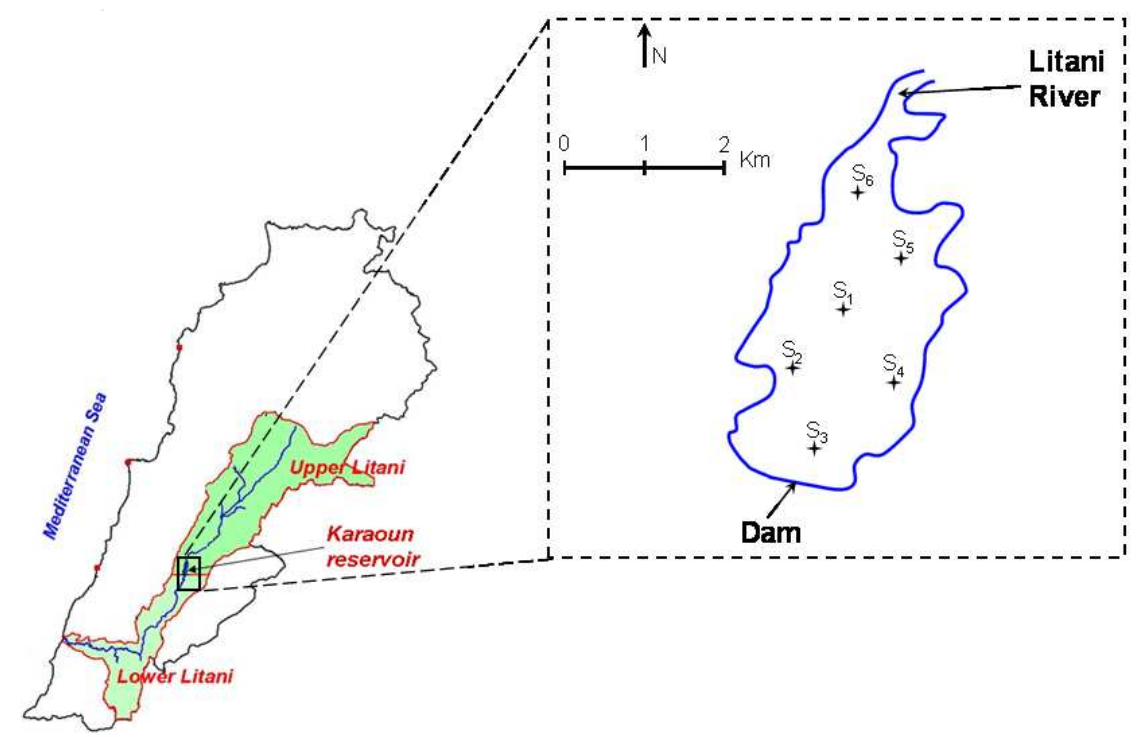

Figure 1 Lake Karaoun and sampling sites: $S_{1}\left(33^{\circ} 56^{\prime} 55^{\prime}\right.$ 'N, $\left.35^{\circ} 69^{\prime} 47^{\prime \prime} \mathrm{E}\right)$; $S_{2}\left(33^{\circ} 55^{\prime} 64\right.$ ' $\mathrm{N}, 3^{\circ} 68^{\prime}$,

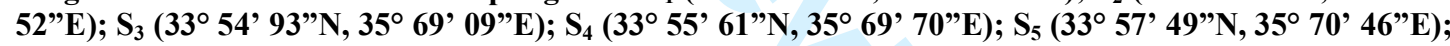
$\mathrm{S}_{6}\left(33^{\circ} 58^{\prime} 73\right.$ ” N, $\left.35^{\circ} 69^{\prime}, 64 " \mathrm{E}\right)$.

\section{Materials and methods}

\subsection{Field measurements}

\subsubsection{Water and phytoplankton samples}

Water samples were taken monthly, between 11:00 and 12:00 h during the study period, at the most representative point ( $\mathrm{S} 1)$, in the middle of the lake $\left(33^{\circ} 56^{\prime} 55^{\prime \prime} \mathrm{N}, 35^{\circ} 69^{\prime} 47^{\prime \prime} \mathrm{E}\right)$. However, during blooms formation, profiles measurements and sampling for water analysis were performed in 6 points that represent all the zones of the lake (Figure 1). Water samples were collected by lowering the polyethylene bottles to about $0.5 \mathrm{~m}$ beneath the water level and stored at $4^{\circ} \mathrm{C}$ until further processing in the laboratory.

Phytoplankton samples were harvested with a plankton net (20 $\mu \mathrm{m}$ mesh size) at the top $10 \mathrm{~m}$ depth and fixed with formaldehyde at a $5 \%(\mathrm{v} / \mathrm{v})$ final concentration.

\subsubsection{Phycocyanin profile measurements}

The TriOS microFlu-blue sensor was used to measure profiles of phycocyanin, a pigment specific to cyanobacteria. TriOS microFlu-blue sensor is a miniaturized submergeable fluorometer (diameter $48 \mathrm{~mm}$ and length $200 \mathrm{~mm}$ ). The probe is equipped with ultra-bright red LED, having an excitation wavelength of $620 \mathrm{~nm}$, an emission wavelength (detector) of 
$655 \mathrm{~nm}$ and a band-width of $10 \mathrm{~nm}$. A recent study by Brient et al. [18] assessed the performance of this submersible probe for measuring phycocyanin-specific fluorescence as a function of cyanobacterial biomass.

\subsubsection{Water temperature, $\mathrm{pH}$ and conductivity measurements}

Continuous water temperature measurements were performed in a 15 minutes time interval using Seastar temperature sensors at 1 and $12 \mathrm{~m}$ to monitor thermal stratification. Also, fast water temperature and conductivity profiles at the six sites $\left(\mathrm{S}_{1}, \mathrm{~S}_{2}, \mathrm{~S}_{3}, \mathrm{~S}_{4}, \mathrm{~S}_{5}\right.$ and $\left.\mathrm{S}_{6}\right)$ were achieved using YSI CastAway CTD probe.

$\mathrm{pH}$ was measured in each sampling site using a field $\mathrm{pH}$ meter (WTW, Weilheim, Germany).

\subsubsection{Dissolved oxygen}

Measurements of dissolved oxygen were conducted at 1 and $4 \mathrm{~m}$ depths using HI 9146 Dissolved Oxygen and Temperature Meter by HANNA instruments.

\subsubsection{Transparency}

Water transparency was measured using a Secchi disk.

\subsection{Laboratory measurements}

\subsubsection{Chemical analysis}

At the laboratory, subsamples were used to perform chemical analysis. Dissolved nutrient concentrations were analyzed after filtering water through Whatman GF/C filters. Nitrates, nitrites and orthophosphates analyses were performed according to standard method procedures [19].

\subsubsection{Microscopic identification}

The cyanobacteria species were determined according to taxonomic keys based on cell structure and dimension, colony morphology, and mucilage characteristics. Microscopic identifications were carried out under a phase contrast microscope (Nikon TE200, Nikon, Melville, NY, USA)

\subsubsection{Chlorophyll-a quantification}

Chlorophyll-a quantification was carried out according to Lorenzen method [20]. Samples were filtered using Whatman $\mathrm{GF} / \mathrm{C}$ filters; these filters were kept freezed at $-20{ }^{\circ} \mathrm{C}$ for 16 hours and then extracted in $90 \%$ acetone by ultrasonication and agitation. The extracts were centrifuged at $3500 \mathrm{rpm}$ for $10 \mathrm{~min}$ to reduce the turbidity. About $4 \mathrm{ml}$ were used for chlorophyll-a quantification using the LaboTech UV/VIS spectrophotometer, then chlorophyll-a correction step was performed by adding $150 \mu \mathrm{l}$ of $0.1 \mathrm{~N} \mathrm{HCL}$ to these $4 \mathrm{ml}$ to measure the amount of degradation product, pheophytin-a.

\subsection{Meteorological and Hydrological data}

Meteorological data (precipitation and air temperature) were obtained from Tal-Amara meteorological Station of the Lebanese Agriculture Research Institute located in the Bekaa valley, $30 \mathrm{~km}$ far from Lake Karaoun. Hydrological data related to Lake Karaoun were provided by the Litani River Authority (LRA), responsible for the management of the Lake. 


\section{Results}

\subsection{Meteorological and hydrological evolution}

In spite of the global warming, the analysis of meteorological data of Lake Karaoun between the years 2001 and 2010 showed an increasing trend of the average annual temperature with highest temperature value $\left(25.7^{\circ} \mathrm{C}\right)$ reached in 2010 . In addition to increased temperature, average annual precipitation in Lake Karaoun was highly altered with an obvious decreasing trend between 2003 and 2007 and lowest precipitation levels in year 2010 (Figure 2).

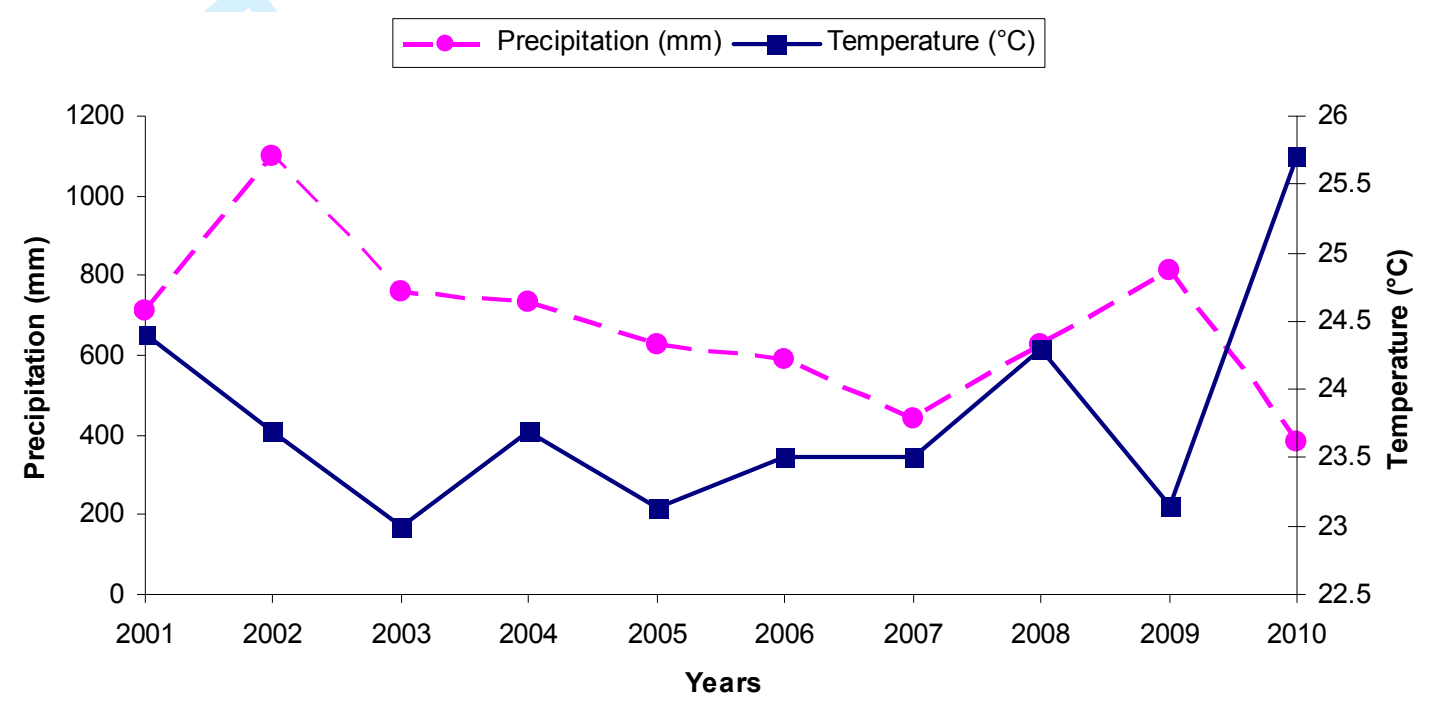

Figure 2 Evolution of average annual temperature and precipitation in Lake Karaoun between 2001 and 2010

In terms of Litani River inflow, Litani River authority measurements on the average annual flow at Lake Karaoun showed significant long term effect of global warming on this freshwater body. The river flow at Lake Karaoun between 1931 and 1961 was estimated at $411.10^{6} \mathrm{~m}^{3} /$ year. This annual flow has decreased greatly to reach $268.10^{6} \mathrm{~m}^{3} /$ year for the period extending from 1998 to 2009. Moreover, in summer season the river monthly inflow rate was reduced from $5 \mathrm{~m}^{3} / \mathrm{s}$ before 1961 to less than $1 \mathrm{~m}^{3} / \mathrm{s}$ after the year 1998 (Figure 3). 


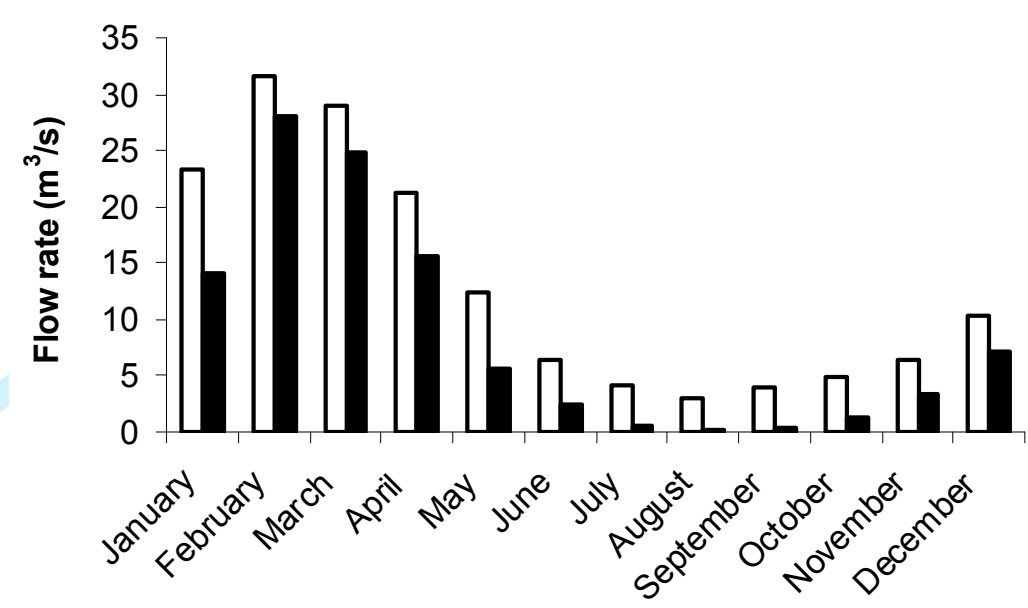

Figure 3 Litani River monthly flows at Lake Karaoun.

\subsection{Cyanobacterial bloom and limnological conditions}

As a result of climate warming, the phytoplankton in Lake Karaoun has been dominated by cyanobacterial bloom since 2009 which consisted of Aphanizomenon ovalisporum and Microcystis aeruginosa. The bloom period was persistent from late spring (May) until late fall (December) for 3 consecutive years ([15], this study). There is a number of measurable physicochemical and environmental parameters can be related to toxic cyanobacterial growth and abundance.

The $\mathrm{pH}$ ranged from 7.29 to 8.34 during winter but tended to increase during the summer months reaching values between 8.72 and 9. The high $\mathrm{pH}$ value of water is due to high photosynthetic following excessive bloom period. It is well known that $\mathrm{pH}$ can rise up to a value close to 9 with excessive proliferation of Microcystis sp. and Aphanizomenon sp. as well as with increasing cyanotoxins production. It was observed that during cyanobacterial blooms the Secchi disc transparency of water in Lake Karaoun was generally very low with the average values recoded between 0.75 and $1.25 \mathrm{~m}$. Whereas the transparency during winter and spring periods was higher reaching $3 \mathrm{~m}$. Specific conductivity ranged between 408 and $421 \mu \mathrm{S} / \mathrm{cm}$ during autumn and ranged between 411 and $446 \mu \mathrm{S} / \mathrm{cm}$ during bloom formation periods.

Measurement of chlorophyll-a is of great importance since it defines the water quality. Chlorophyll-a was high during the period of cyanobacterial bloom, it reached a peak of 148 $\mu \mathrm{g} / \mathrm{l}$ in 2012. The monitoring of cyanobacteria in the Karaoun water body was also carried out using a minifluorimeter specific to the fluorescence of phycocyanin, a pigment specific to cyanobacteria. Phycocyanin has been considered a as a marker of total cyanobacterial biomass in the same way as chlorophyll a. Maximum phycocyanin concentrations were recorded in summer during thermal stratification. Through all the sites measured in the lake, fluorescence peak was occurring at $1 \mathrm{~m}$ depth (Figure $4 b$ ). 
a)

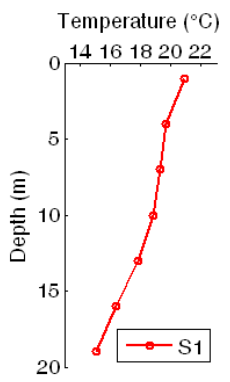

b)

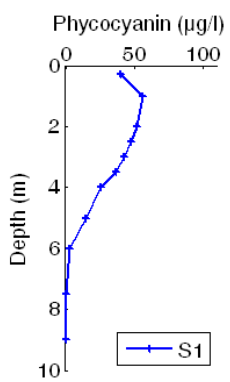

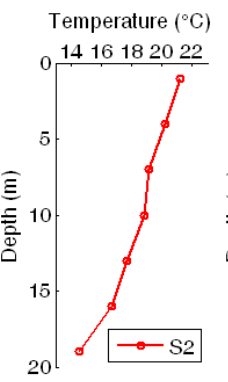
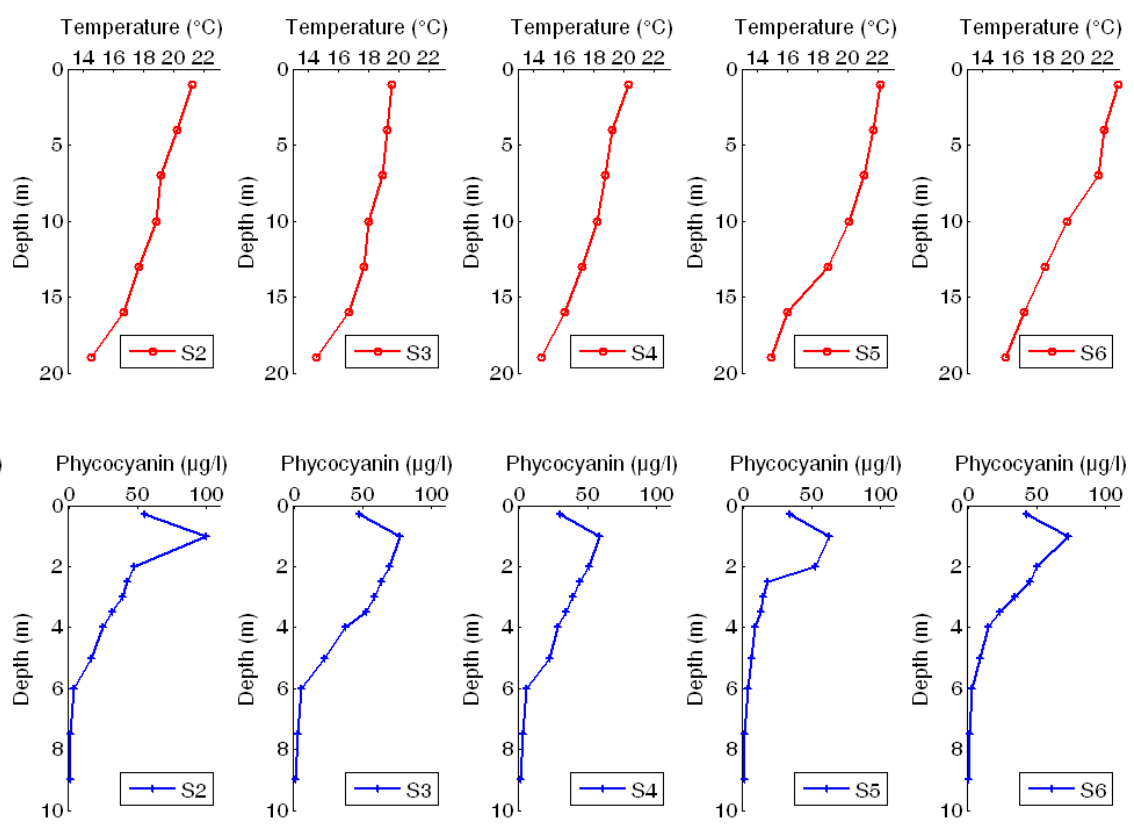

Figure 4 a) Water temperature and b) phycocyanin profiles during bloom formations at Lake Karaoun in 19/06/2012.

Phosphorus is very important for the growth and biomass of algae. Orthophosphate is the phosphorus form that is directly taken up by algae; it constitutes an index of the amount of phosphorus immediately available for algal growth. As expected orthophosphate levels in Lake Karaoun were below detection levels during cyanobacterial blooms. Nitrate levels ranged between 10.2 and $29.34 \mathrm{mg} / \mathrm{l}$, while nitrite levels were almost stable, between 2.1 and $2.8 \mathrm{mg} / \mathrm{l}$.

In spite of dissolved oxygen levels, oxygen was at moderate concentrations all year (between 5.5 and $6.5 \mathrm{ppm}$ ), except for the end of May until November, where there was a remarkable increase in the oxygen concentration (between 8 and $9.5 \mathrm{ppm}$ ) coincided with the cyanobacterial blooms. 
a)

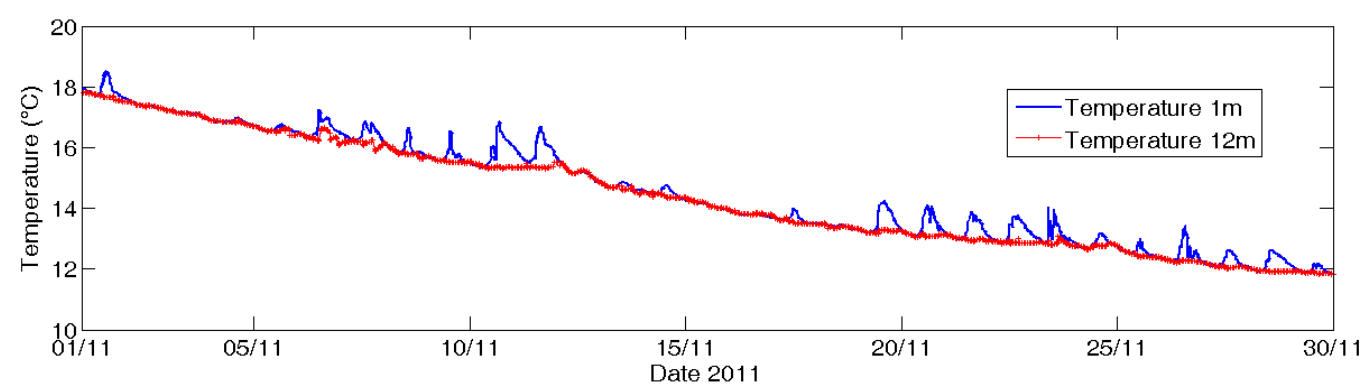

b)

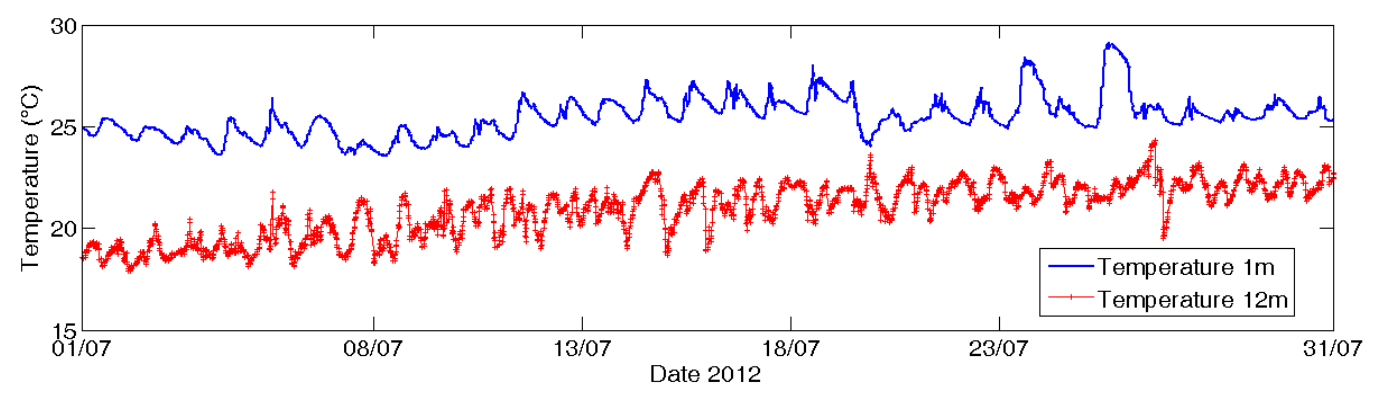

Figure 5 a) Destratification during late autumn (November 2011) b) Stable thermal stratification period during summer (July 2012) at Lake Karaoun.

During one year study period (from October 2011 to October 2012), the surface water temperature ranged from 7 to $29^{\circ} \mathrm{C}$ with the lowest temperatures recorded in February 2011 and the highest in July 2012. Comparison between water temperature measurements at fixed 1 and $12 \mathrm{~m}$ depths in November 2011 shows an absence of any stable thermal stratification for many days (eg. between 02/11 and 06/11), (Figure 5a). Very weak stratification caused by irradiance and increase in air temperature during the day were always broken by vigorous mixing of water column during night. On the other hand, Figure $5 \mathrm{~b}$ showed a strong thermal stratification that ranged from 4 to $6^{\circ} \mathrm{C}$ between 1 and $12 \mathrm{~m}$ depths in July 2012. This stable thermal stratification was occurring uniformly in all the sites of the lake (Figure 4a).

\section{Discussion}

Changes in plankton community as a result of global warming are a growing concern in ecological studies, as those properties substantially contribute to ecosystem functioning [2123]. According to Paerl et al. [24], climate change can result in modified patterns, intensities and duration of precipitation and droughts. After the end of an intense precipitation event, water residence time will increases due to drought, nutrient load will be captured by receiving water bodies, eventually promoting their bloom potential. Tsugeki et al. [25] concluded that the abundance and composition of algal population in Lake Biwa changed greatly during the 1960 s and 1970s as a consequence of eutrophication. However, even after the cease of eutrophication in 1980s, algal composition including cyanobacteria continued to change in response to inter-annual variations of regional and global meteorological conditions.

Increased lake temperature in deep lakes is connected with higher thermal stability and a deeper thermocline [26, 27]. Increased thermal stability and stratification has been found in many Lakes [28] in relation to increased air temperatures. Lake Karaoun is a deep monomictic water body which is subjected to changing climate during summer, by changing its thermal regime through enhanced thermal stratification (Figure 5). 
In the present work, we analyzed the effect of climate warming on Lake Karaoun, and in particular the thermal stratification, on phytoplankton community and the abiotic factors that are closely related to their growth and abundance. Our results clearly showed that abiotic and biotic lake properties differed substantially between stratification and mixing periods.

The increase in surface water temperatures and the length of thermal stratification as a direct response to increased water temperatures coincided with higher abundance of cyanobacterial bloom in Lake Karaoun (Figure 4). This is in agreement with other studies those reported that climate warming may favour the growth and abundance of cyanobacterial species which are well adapted to higher temperatures and stratified conditions as well [21-22]. Moreover, the stratification period was coincided with low epilimnion nutrient concentrations in the lake. In this period the orthophosphates level were below the detection limit.

Chlorophyll a and phycocyanin concentrations oscillated many times during the period study with the highest value coinciding with a dense cyanobacterial bloom in the lake (Figure 4). Indeed chlorophyll a concentrations were shown to be increasing from year to year. During years 2009 and 2010 the maximum chlorophyll a concentrations ranged from 23 to $31.5 \mu \mathrm{g} / \mathrm{l}$, while in 2011 the maximum concentration ranged from 48 to $60 \mu \mathrm{g} / \mathrm{l}$. However in the year 2012, excessive bloom formations increased the maximum chlorophyll a concentrations that reached a value of $148 \mu \mathrm{g} / \mathrm{l}$. In addition high phycocyanin concentration where also shown to be coincided with chlorophyll-a measurements when the total phytoplankton population consisted only of cyanobacteria species. This is in agreement with [18] showing a strong linear correlation between the phycocyanin concentration and the number of cyanobacterial cells. As with chlorophyll a, the amount of phycocyanin could be used as a tool for monitoring cyanobacteria in freshwater bodies [18].

During periods of continuous mixing in Lake Karaoun (late autumn-winter and early spring), plankton community was composed of chlorophyceae (Staurastrum manfeldetii) and dinophyta (Ceratium hirudinella). This community stayed remarkably unaffected during this mixing period unless some difference in diatom species was observed.

In the past, the phytoplankton of the Lake Karaoun has been dominated by diatom bloom which was accompanied by a high concentration of dinoflagellates and the presence of chlorophyceae $[14,29]$. These species adapted to lower water temperatures and well-mixed conditions in Lake Karaoun [30]. The effect of climate change has adversely affected the relevance of diatom species. Diatoms may face increasingly worse environmental conditions in the future [23], and thus further decrease in relevance within the plankton community in Lake Karaoun.

It should be noted that lower abundance of cyanobacterial biomass recorded in late autumn (November) was due to the decrease in the atmospheric temperature together with the decrease in the water level of the lake and increase in wind speed leading thermal destratification. As expected the reappearance of the dinoflagellate and zooplankton has been observed.

Induced a higher proportion of stratification in Lake Karaoun and especially long stratification events more resistant to mixing by the wind may substantially alter lake functional properties,. eg. by an increase in lake surface water temperature and stability, nutrient depletion in the epilimnion and nutrient pulses from the sediment when the lake bottom becomes anoxic [23, 31, 32].

Rising temperatures favour cyanobacteria in several ways. Cyanobacteria generally grow better at higher temperatures than do other phytoplankton species such as diatoms and green algae [22]. It is well-known that the optimum water temperature for Aphanizomenon 
ovalisporum growth is $19^{\circ} \mathrm{C}$ while Microcystis aeruginosa prefers higher temperatures (often above $25^{\circ} \mathrm{C}$ ) [11]. Warming of surface waters also strengthens the vertical stratification of lakes, reducing vertical mixing. Microcystis and Aphanizomenon exploit these stratified conditions by forming intracellular gas vesicles, which make the cells buoyant. Buoyant cyanobacteria float upward when mixing is weak and accumulate in dense surface blooms $[22,23,31,33]$. These surface blooms shade underlying non-buoyant phytoplankton, thus suppressing their opponents through competition for light [33]. On the other hand the light intensity absorbed by cyanobacteria blooms increases water temperature [22, 33]. Hence, climate-induced thermal stratification of the Lake Karaoun remarkably alters abiotic lake characteristics and consequently the phytoplankton community towards shifting into higher relevance of nitrogen-fixation cyanobacteria.

\section{Conclusion}

Studies on the evolution of cyanobacteria, their ecophysiology, and recent investigations on the dynamics of phytoplankton community structure in response to global warming suggest that cyanobacteria are well adapted to higher water temperatures and more stable, stratified conditions. Some cyanobacteria produce toxins that may have toxic effects on aquatic biodiversity as well as negative human health effect by ingestion of water or by contact with water. Our study over 3 years in Lake Karaoun confirm the hypothesis on the influence of weather conditions, including global warming on the occurrence and formation of cyanobacterial blooms, including both the genotoxic Microcystis aeruginosa and Aphanizomenon ovalisporum. The contribution of excessive nutrients from domestic sewage, industrial leaching rich in phosphates also promotes cyanobacterial proliferation. The negative ecological consequences for the functioning of the lake is the loss of both flora and fauna biodiversity in addition to the degradation of the quality of riparian life.

\section{References}

[1] D. Li, F. Kong, X. Shi, L. Ye, Y. Yu and Z. Yang, Quantification of microcystin-producing and non-microcystin producing Microcystis populations during the 2009 and 2010 blooms in Lake Taihu using quantitative real-time pcr, J. Environ. Sci., 24(2) (2012) 284-290.

[2] S. Jacquet, J. F. Briand, C. Leboulanger, C. Avois-Jacquet, L. Oberhaus, B. Tassin and B. Vinçon-Leite, The proliferation of the toxic cyanobacterium Planktothrix rubescens following restoration of the largest natural French lake (Lac du Bourget), Harmful Algae, 4 (2005) 651672.

[3] S. Gkelis, M. Moustaka-Gouni, K. Sivonen and T. Lanaras, First report of the cyanobacterium Aphanizomenon ovalisporum Forti in two Greek lakes and cyanotoxin occurrence, J. Plankton Res., 27(12) (2005) 1295-1300.

[4] D. Chonudomkul, W. Yongmanitchai, G. Theeragool, M. Kawachi, F. Kasai, K. Kaya and M. M. Watanabe, Morphology, genetic diversity, temperature tolerance and toxicity of Cylindrospermopsis raciborskii (Nostocales, cyanobacteria) strains fromThailand and Japan, FEMS Microbiol. Ecol., 48(3) (2004) 345-355.

[5] S. Azevedo, W. Carmichael, E. Jochimsen and K. Rinehart, Human intoxication by microcystins during renal dialysis treatment in Caruara-Brazil, Toxicol., 181 (2002) 441-446.

[6] G.A. Codd, S. Bell, K. Kaya, C. Ward, K. Beattie and J. Metcalf, Cyanobacterial toxins, exposure routes and human health, Europ. J. Phycol., 34(4) (1999) 405-415.

[7] G. A. Codd, L. F. Morrison and J. S. Metcalf, Cyanobacterial toxins: Risk management for health protection, Toxicol. and Applied Pharmacol., 203(3) (2005) 264-272. 
[8] I. Yoshinaga, T. Hitomi, Miura, Asa, Shiratani, Eisaku, Miyazaki and Tatsuo, Cyanobacterium Microcystis bloom in a eutrophicated regulating reservoir, vol. 40, Ministry of Agriculture, Forestry, and Fisheries, Ibaraki, Japan, 2006.

[9] H. W. Paerl and V. J. Paul, Climate change: Links to global expansion of harmful cyanobacteria, Water Res., 46(5) (2012) 1349-1363.

[10] C. Ye, Z. Shen, T. Zhang, M. Fan, Y. Lei and J. Zhang, Long-term joint effect of nutrients and temperature increase on algal growth in Lake Taihu, China, J. Environ. Sci., 23(2) (2011) 222227.

[11] R. D. Robarts and T. Zohary, Temperature effects on photosynthetic capacity, respiration, and growth rates of bloom-forming cyanobacteria, New Zealand J. Marine and Freshwater Res., 21(3) (1987) 391 - 399.

[12] F. Peeters, D. Straile, A. Lorke and D. M. Livingstone, Earlier onset of the spring phytoplankton bloom in lakes of the temperate zone in a warmer climate, Global Change Biology, 13(9) (2007) 1898-1909.

[13] K. Slim, A. Atoui, G. Elzein and M. Temsah, Effets des facteurs environnementaux sur la qualité de l'eau et la prolifération toxique des cyanobactéries du lac Karaoun (Liban), Larhyss J., 10 (2012) 29-43.

[14] K. Slim, Contribution to the study of the flora of the basin of the Litani basin, Leb. Sci. Res. Report., 1 (1996) 65-73.

[15] A. Atoui, H. Hafez and K. Slim, Occurrence of toxic cyanobacterial blooms for the first time in Lake Karaoun, Lebanon, Water and Environ. J., 27 (2012) 42-49

[16] K. J. Sene, T. J. March and A. Hachache, An assessment of the difficulties in quantifying the surface water resources of lebanon, Hydrol. Sci. J. 44(1) (1999) 79-96.

[17] S. Korfali, M. Jurdi and B. Davies, Variation of metals in bed sediments of Qaraaoun reservoir, lebanon, Environ. Monit. and Assess., 115(1) (2006) 307-319.

[18] L. Brient, M. Lengronne, E. Bertrand, D. Rolland, A. Sipel, D. Steinmann, I. Baudin, M. Legeas, B. Le Rouzic and M. Bormans, A phycocyanin probe as a tool for monitoring cyanobacteria in freshwater bodies, J. Environ. Monit., 10 (2008) 248-255.

[19] APHA, Standard Methods (20th edn), American Public Health Association, Washington, DC, 1999.

[20] C. J. Lorenzen, Determination of chlorophyll and phaeo-pigments: Spectrophotometric equations, limnol. Oceanogr., 12 (1967) 343-346.

[21] K. D. Jöhnk, J. E. F. Huisman, J. Sharples, B. E. N. Sommeijer, P. M. Visser and J. M. Stroom, Summer heatwaves promote blooms of harmful cyanobacteria, Global Change Biol., 14(3) (2008) 495-512.

[22] H. W. Paerl and J. Huisman., Climate - blooms like it hot, Science 320 (2008), 57-58.

[23] C. Wagner and R. Adrian, Cyanobacteria dominance: Quantifying the effects of climate change, Limnol. Oceanogr., 52 (2009) 2460-2468.

[24] H. W. Paerl and J. Huisman, Climate change: A catalyst for global expansion of harmful cyanobacterial blooms, Environ. Microbiol. Reports, 1(1) (2009) 27-37.

[25] N. K. Tsugeki, J. Urabe, Y. Hayami, M. Kuwae and M. Nakanishi, Phytoplankton dynamics in lake biwa during the 20th century: Complex responses to climate variation and changes in nutrient status, J. Paleolimnol., 44(1) (2010), 69-83.

[26] B. T. DeStasio, D. K. Hill, J. M. Kleinhans, N. P. Nibbelink and J. J. Magnuson, Potential effects of global climate change on small north-temperate lakes: Physics, fish, and plankton. , limnol. Oceanogr., 41 (1996) 1136-1149.

[27] H. Hassan, T. Aramaki, K. Hanaki, T. Matsuo and R. Wilby, Lake stratification and temperature profiles simulated using downscaled gcm output, Water Sci. and Technol., 38(11) (1998) 217-226.

[28] D. Livingstone, Impact of secular climate change on the thermal structure of a large temperate central european lake, Climatic Change, 57(1-2) (2003) 205-225.

[29] Z. Saad, K. Slim, G. Elzein and O. Elsamad, Evaluation of the water quality of karaoun reservoir (lebanon), Bull. Soc. Neuchatel. Sci. Nat., 128 (2005) 71-80.

[30] C. S. Reynolds, V. Huszar, C. Kruk, L. Naselli-Flores and S. Melo, Towards a functional classification of the freshwater phytoplankton, J. Plankton Res., 24(5) (2002) 417-428. 
[31] S. Wilhelm and R. Adrian, Impact of summer warming on the thermal characteristics of a polymictic lake and consequences for oxygen, nutrients and phytoplankton, Freshwater Biol., 53(2) (2008) 226-237.

[32] H. W. Paerl, N. S. Hall and E. S. Calandrino, Controlling harmful cyanobacterial blooms in a world experiencing anthropogenic and climatic-induced change, Sci. of the Total Environ., 409(10) (2011) 1739-1745.

[33] B. W. Ibelings, M. Vonk, H. F. J. Los, D. T. Van Der Molen and W. M. Mooij, Fuzzy modeling of cyanobacterial surface waterblooms: Validation with NOAA-AVHRR satellite images. Ecol. Applications, 13(5) (2003) 1456-1472. 


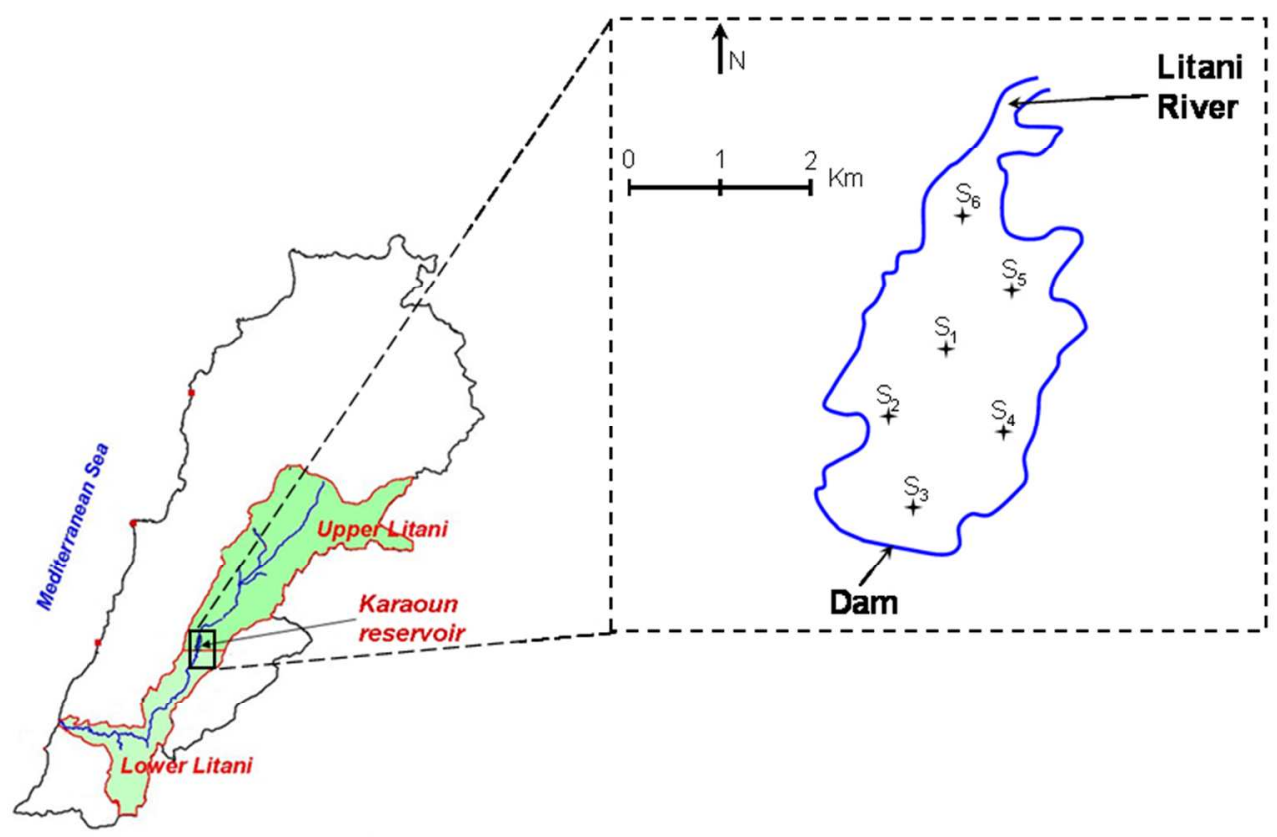

$180 \times 114 \mathrm{~mm}(120 \times 120 \mathrm{DPI})$ 


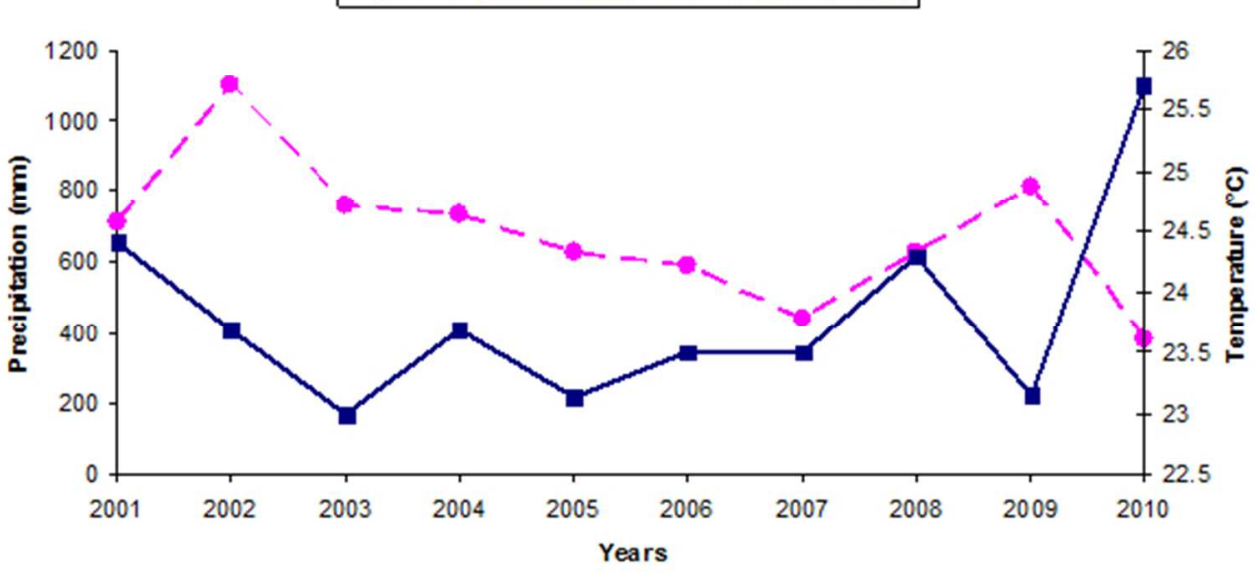

$126 \times 60 \mathrm{~mm}(120 \times 120 \mathrm{DPI})$ 

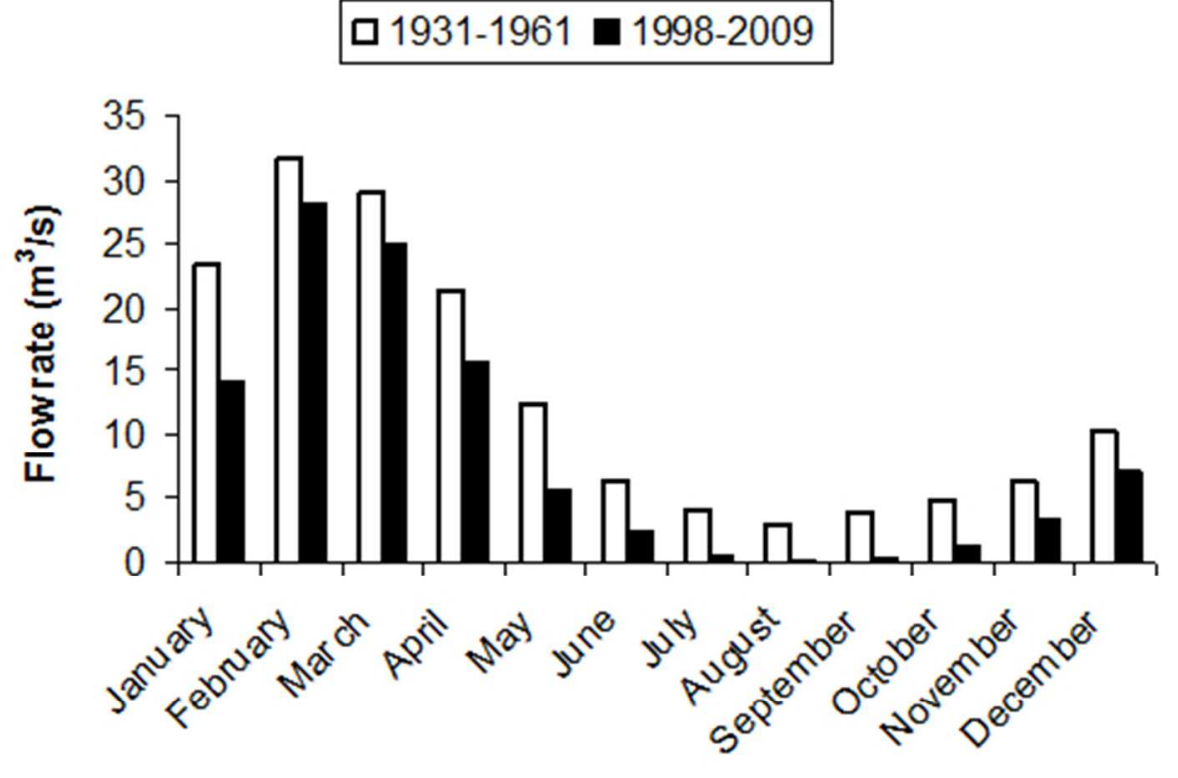

$113 \times 75 \mathrm{~mm}(120 \times 120$ DPI $)$ 
a)
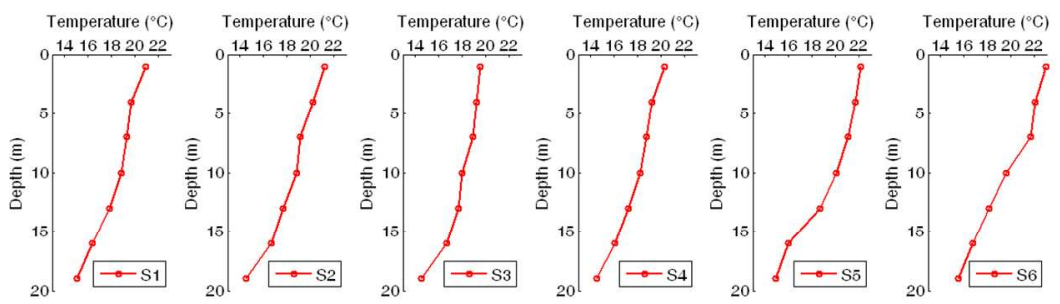

b)
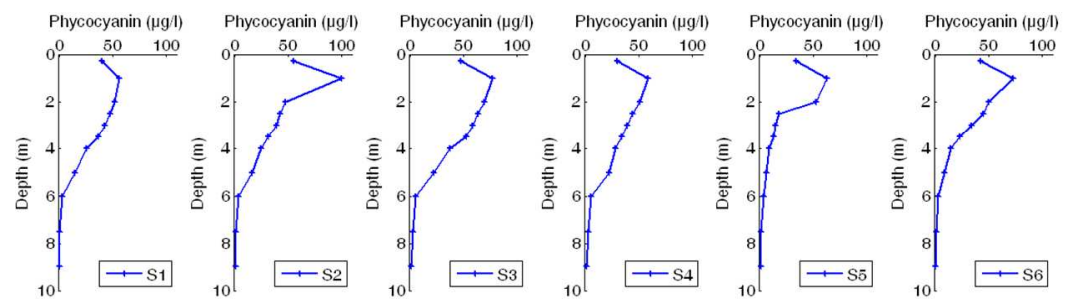

$305 \times 168 \mathrm{~mm}(120 \times 120 \mathrm{DPI})$ 
a)

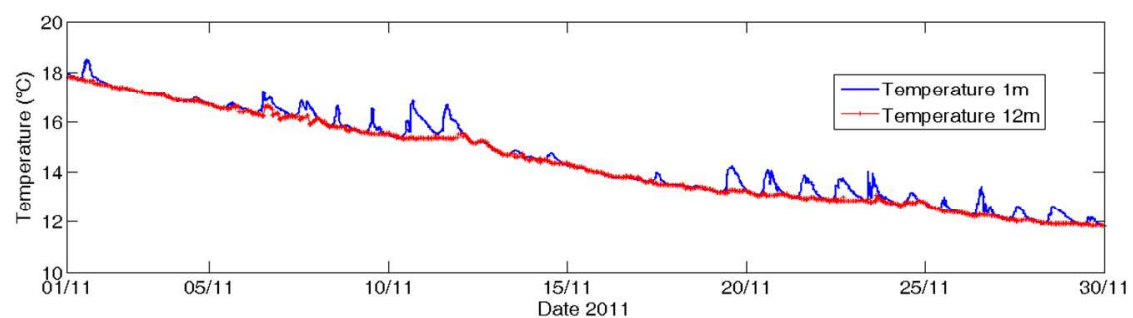

b)

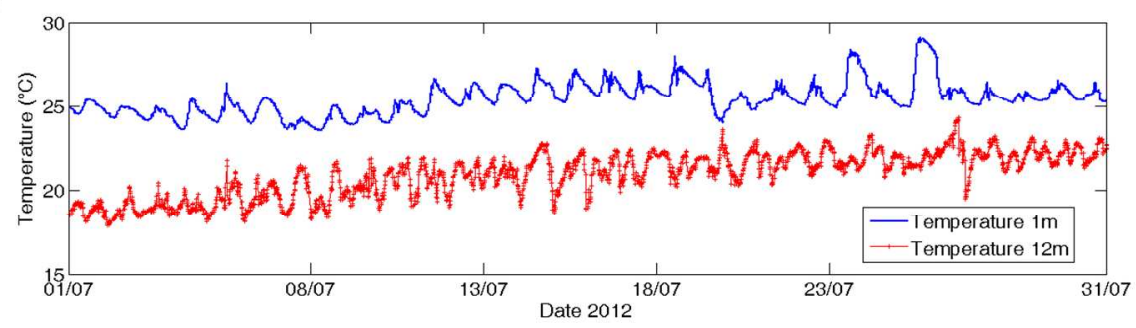

$296 \times 161 \mathrm{~mm}(120 \times 120$ DPI $)$ 